\title{
STUDY ON MECHANICAL PROPERTIES AND MICROSTRUCTURE OF 42CrMo4/NANOS-BA ${ }^{\circledR}$ HIGH-STRENGTH CLAD PLATES AFTER THE PROCESS OF HOT ROLLING AND TWO-STAGE HEAT TREATMENT WITH ISOTHERMAL TRANSFORMATION
}

\author{
BADANIA WŁAŚCIWOŚCI MECHANICZNYCH I MIKROSTRUKTURY \\ WYSOKOWYTRZYMAEYCH PEASKOWNIKÓW DWUWARSTWOWYCH \\ 42CrMo4/NANOS-BA ${ }^{\circledR}$ PO PROCESIE WALCOWANIA NA GORĄCO \\ I DWUETAPOWEJ OBRÓBCE CIEPLNEJ Z PRZEMIANĄ IZOTERMICZNĄ
}

\begin{abstract}
The aim of the study was to develop a technology for welding non-weldable $42 \mathrm{CrMo} 4$ and NANOS-BA ${ }^{\circledast}$ steel grades in the process of hot rolling and two-stage heat treatment. As a result of physical experiments carried out in a line for semi-industrial simulation of the production of metals and their alloys (LPS) and additional heat treatment, a durable combination of 42CrMo4 and NANOS-BA ${ }^{\circledR}$ steels with high mechanical properties was obtained, including: $R_{p 0.2}=1036 \mathrm{MPa}, R_{m}=1504 \mathrm{MPa}$ and $\mathrm{A}=10.9 \%$, without microscopically visible cracks and other discontinuities in the joined surface. The quality of the $42 \mathrm{CrMo} 4 / N A N O S-B A^{\otimes}$ clad plates produced in this way was assessed on the basis of microstructure examination as well as bending, shear and tensile strength tests.
\end{abstract}

Keywords: clad plates, hot rolling bonding, nanostructured steel

\section{INTRODUCTION}

One of the main reasons for the interest of research centres in the development of technologies for the production of new layered materials is the possibility of obtaining unique functional properties for this type of product. Welding steels with a carbon equivalent $\mathrm{C}_{\text {eq }} \geq 0.45$ (difficult to weld, prone to cracking) using traditional methods does not guarantee obtaining the necessary operational properties of welded joints [1]. Joining non-weldable NANOS-BA ${ }^{\circledR}$ steels $\left(C_{\text {eq }}=1.34\right)$ with other steel grades using standard welding methods is currently not possible [2]. An alternative solution is the possibility of welding layers of non-weldable $42 \mathrm{CrMo} 4$ and NANOS-BA steel grades together in the process of hot rolling and two-stage heat
Celem pracy byto opracowanie technologii zgrzewania niespawalnych stali $w$ gatunkach $42 \mathrm{CrMo4} i$ NANOS-BA ${ }^{\circledR} w$ procesie walcowania na goraco $i$ dwuetapowej obróbki cieplnej. W wyniku fizycznych eksperymentów przeprowadzonych $w$ linii do pótprzemystowej symulacji wytwarzania metali $i$ ich stopów (LPS) $i$ dodatkowej obróbki cieplnej uzyskano trwate potaczenie stali 42CrMo4 i NANOS-BA ${ }^{\circledast}$ o wysokich wtaściwościach mechanicznych m.in.: $R_{p 0,2}=1036 \mathrm{MPa}, R_{m}=1504 \mathrm{MPa}$ i A $=10,9 \%$, bez widocznych mikroskopowo pęknięć i innych nieciagtości w płaszczyźnie zgrzewania. Ocenę jakości wykonanych tym sposobem połaczeń ptaskowników dwuwarstwowych 42CrMo4/NANOS-BA ${ }^{\circledR}$ dokonano $w$ oparciu o badania mikrostruktury i próby wytrzymałości na zginanie, ścinanie i rozciaganie.

Stowa kluczowe: blachy platerowane, zgrzewanie poprzez walcowanie na goraco, stal nanostrukturalna treatment. The high mechanical properties of the experimental NANOS-BA steel, including $R_{\mathrm{p} 0.2}=1315 \mathrm{MPa}$, $R_{\mathrm{m}}=2103 \mathrm{MPa}$ and $A=14.3 \%$ create potential for the use of this grade, e.g. in the mining or defence industry [3, 4]. The possibility of using NANOS-BA steel in the form of a layer applied to structural steel may extend the scope of its application. Currently, the literature does not present the results of tests of joining $42 \mathrm{CrMo} 4$ and NANOS-BA ${ }^{\circledR}$ steels in the process of hot rolling and heat treatment. This study is a continuation of the research carried out at the Łukasiewicz Research Network - Institute of Ferrous Metallurgy (Łukasiewicz - IMŻ) on the possibility of producing highstrength clad plates, composed of layers of the experimental NANOS-BA ${ }^{\circledast}$ steel grade. The conducted experiments of welding various grades of steel together in the hot rolling 
process at Łukasiewicz - IMŻ in 2018-2019 resulted in the development of a preliminary technology for joining layers of $42 \mathrm{CrMo} 4$ and NANOS-BA ${ }^{\circledR}$ steels. As a result of the tests, a technology was developed that allows to obtain the following mechanical properties of $42 \mathrm{CrMo} 4$ NANOS-BA $^{\circledast}$ clad plates: $R_{\mathrm{p} 0.2}=590 \mathrm{MPa}, R_{\mathrm{m}}=1056 \mathrm{MPa}$ and $A=2 \%$ in the condition after hot plastic processing in one pass with a relative draft of $\sim 40 \%$ and intermediate (softening) annealing $[5,6]$. The study proposes new variants of hot

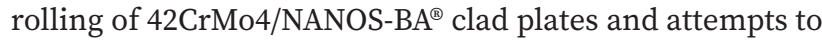
optimize the microstructure while increasing the functional properties of clad plates through the use of additional, controlled isothermal annealing with phase transformation of NANOS-BA ${ }^{\circledR}$ steel into nanostructured bainite with an assumed very high strength.

\section{MATERIAL AND METHODOLOGY}

The research material consisted of clad plates, composed of $42 \mathrm{CrMo} 4$ and NANOS-BA ${ }^{\circledR}$ steel layers. The basic material was commercial, non-weldable $42 \mathrm{CrMo} 4$ steel. The applied material was experimental, non-weldable NANOS-BA ${ }^{\circledast}$ steel. The chemical compositions of the steels used for the layers of $42 \mathrm{CrMo} 4 / \mathrm{NANOS}-\mathrm{BA}^{\circledR}$ clad plates and their selected mechanical properties after heat treatment are presented in Tables 1 and 2, respectively.

Before hot rolling bonding, the clad plates made of the $42 \mathrm{CrMo} 4$ and NANOS-BA ${ }^{\circledR}$ steel grades were mechanically machined to the same final dimensions: thickness $10 \mathrm{~mm} \times$ width $140 \mathrm{~mm} \times$ length $240 \mathrm{~mm}$. The layers were degreased on contact surfaces and then joined together into packages (two-layer input) with a thickness of $20 \mathrm{~mm}$ each.

Attempts to join $42 \mathrm{CrMo} 4$ and NANOS-BA ${ }^{\circledR}$ steel layers were carried out in the hot rolling process in a line for semi-industrial simulation of the production of metals and their alloys (LPS) at the Eukasiewicz Research Network Institute of Ferrous Metallurgy. The two-layer input was heated in a heating chamber furnace to a temperature $100^{\circ} \mathrm{C}$ higher than the temperature planned for the beginning of plastic processing, and then hot rolled into clad plates, according to the following variants:
- in one pass, with a $\sim 40 \%$ reduction ratio (variant 1),

- in two passes, with a $\sim 30 \%$ reduction ratio each (variant 2),

- in three passes, with a $\sim 30 \%$ reduction ratio each (variant 3).

Slow cooling was applied in order to reduce the possibility of cracking during cooling of the $42 \mathrm{CrMo} 4 / \mathrm{NANOS} \mathrm{BA}^{\circledR}$ clad plates after hot plastic processing. For this purpose, immediately after rolling, the clad plates were loaded into a furnace heated to $690^{\circ} \mathrm{C}$, annealed for 4 hours, and then cooled, together with the furnace, to ambient temperature. In the next stage, additional heat treatment was performed on the samples taken from the clad plates marked with the symbols S1, S2 and S3, which shaped the final mechanical properties of the layers of NANOS-BA ${ }^{\circledR}$ steel as a result of the phase transformation of austenite into nano-structured bainite. The additional heat treatment included austenitisation of the samples at $940^{\circ} \mathrm{C}$ for 40 minutes, subsequent isothermal annealing in a furnace chamber at $210^{\circ} \mathrm{C}$ for 120 hours, and finally free cooling in air. Table 3 presents a list of materials joined into clad plates No. S1, S2 and S3 along with appropriate variants of hot plastic processing and two-stage heat treatment.

The quality of the manufactured connections of the $42 \mathrm{CrMo} 4$ and NANOS-BA ${ }^{\circledR}$ steels in the hot rolling process with direct intermediate annealing and additional heat treatment was evaluated in bending, tensile and shear strength tests as well as in metallographic tests. The samples for testing mechanical properties and microstructure were taken from clad plates in the direction of rolling (longitudinal samples).

The guidelines for the bending test were adopted on the basis of the PN-EN ISO 7438 standard [7] and dependence (1).

$$
l=(D+3 a) \pm a / 2
$$

where:

$l$ - distance between supports, [mm]

$D$ - diameter of the shaft and support rollers, [mm]

$a$ - thickness of the layered or monolithic sample, [mm].

Table 1. Chemical compositions of steel layers intended for clad plates, [weight \%]

Tabela 1. Składy chemiczne stali przeznaczonych na płaskowniki platerowane, [\% masowe]

\begin{tabular}{|c|c|c|c|c|c|c|c|c|c|c|c|c|c|c|c|}
\hline Material & \multicolumn{15}{|c|}{ Component content $\square$ Zawartość składnika } \\
\hline \multirow{2}{*}{ 42CrMo4 } & $\mathbf{C}$ & Mn & Si & $\mathbf{P}$ & $\mathbf{S}$ & $\mathbf{C r}$ & $\mathbf{N i}$ & Mo & $\mathbf{C u}$ & Al & $\mathbf{N}$ & $\mathbf{V}$ & $\mathbf{N b}$ & $\mathbf{T i}$ & $C_{\text {eq }}$ \\
\hline & 0.40 & 0.68 & 0.26 & 0.014 & 0.004 & 0.934 & 0.070 & 0.2030 & 0.122 & 0.032 & 0.008 & 0.003 & 0.0034 & 0.0019 & 0.75 \\
\hline \multirow{2}{*}{ NANOS-BA ${ }^{\circledR}$} & C & Mn & Si & $\mathbf{P}$ & $\mathbf{S}$ & $\mathrm{Cr}$ & $\mathbf{V}$ & $\mathrm{Cu}$ & Mo & Ti & $C_{\text {eq }}$ & & & & \\
\hline & 0.58 & 1.90 & 1.82 & 0.012 & 0.005 & 1.32 & 0.095 & - & 0.75 & 0.010 & $1.34-1.4$ & & & & \\
\hline
\end{tabular}

Table 2. Mechanical properties of steels for clad plates

Tabela 2. Właściwości mechaniczne stali przeznaczonych na płaskowniki platerowane

\begin{tabular}{|c|c|c|c|c|c|}
\hline \multirow{2}{*}{$\begin{array}{l}\text { Steel grade } \\
\text { Gatunek } \\
\text { stali }\end{array}$} & \multirow{2}{*}{$\begin{array}{c}\text { Variant of isothermal } \\
\text { heat treatment } \\
\text { Wariant obróbki } \\
\text { cieplnej izotermicznej }\end{array}$} & $\begin{array}{l}\text { Yield strength } \\
\text { Granica plastyczności }\end{array}$ & $\begin{array}{c}\text { Tensile strength } \\
\text { Wytrzymałość na } \\
\text { rozciąganie }\end{array}$ & $\begin{array}{l}\text { Total elongation } \\
\text { Wydłużenie całkowite }\end{array}$ & $\begin{array}{c}\text { Ratio } \\
\text { Współczynnik }\end{array}$ \\
\hline & & $R_{\mathrm{p} 0.2},[\mathrm{MPa}]$ & $R_{\mathrm{m}},[\mathrm{MPa}]$ & $A,[\%]$ & $R_{\mathrm{p} 0.2} / R_{\mathrm{m}}$ \\
\hline 42CrMo4 & - & 610 & 924 & 13.8 & 0.66 \\
\hline \multirow{2}{*}{ NANOS-BA ${ }^{\circledR}$} & $210 / 120$ & 1315 & 2103 & 14.3 & 0.63 \\
\hline & $275 / 120$ & 1250 & 1713 & 18.8 & 0.73 \\
\hline
\end{tabular}


Table 3. List of materials intended for clad plates with variants of hot rolling and heat treatment to which they were subjected Tabela 3. Zestawienie materiałów przeznaczonych na płaskowniki warstwowe wraz z wariantami walcowania na gorąco i obróbki cieplnej, którym zostały poddane

\begin{tabular}{|c|c|c|c|c|c|}
\hline $\begin{array}{l}\text { No. } \\
\text { Lp. }\end{array}$ & $\begin{array}{c}\text { Sign of clad plates } \\
\text { Oznaczenie płaskownika } \\
\text { platerowanego }\end{array}$ & $\begin{array}{l}\text { Base layer } \\
\text { Warstwa podstawowa }\end{array}$ & $\begin{array}{l}\text { Cladding layer } \square \\
\text { Warstwa nakładana }\end{array}$ & $\begin{array}{c}\text { Stage 1. direct heat } \\
\text { treatment } \\
\text { Etap 1. obróbka cieplna } \\
\text { bezpośrednio po } \\
\text { walcowaniu na gorąco }\end{array}$ & $\begin{array}{l}\text { Stage 2. additional the } \\
\text { heat treatment } \\
\text { Etap 2. dodatkowa } \\
\text { obróbka cieplna }\end{array}$ \\
\hline \multicolumn{4}{|c|}{$\begin{array}{l}\text { Variant } 1 \text {, in one pass, with a } \sim 40 \% \text { reduction ratio } \\
\text { Wariant } 1 \text {, jeden przepust } \mathrm{z} \text { gniotem względnym } \sim 40 \%\end{array}$} & \multirow{6}{*}{$\begin{array}{l}\text { Softening annealing }{ }^{1)} \\
\text { Wyżarzanie zmiękczające }\end{array}$} & \multirow{6}{*}{$\begin{array}{c}\text { Isothermal annealing }^{2} \\
\text { Wyżarzanie } \\
\text { izotermiczne }^{2)}\end{array}$} \\
\hline 1 & S1 & 42CrMo4 & NANOS-BA ${ }^{\circledast}$ & & \\
\hline \multicolumn{4}{|c|}{$\begin{array}{l}\text { Variant } 2 \text {, in two passes, with a } \sim 30 \% \text { reduction ratio each } \\
\text { Wariant } 2 \text {, dwa przepusty z gniotem względnym } \sim 30 \% \text { każdy }\end{array}$} & & \\
\hline 2 & $\mathrm{~S} 2$ & 42CrMo4 & NANOS-BA ${ }^{\circledast}$ & & \\
\hline \multicolumn{4}{|c|}{$\begin{array}{l}\text { Variant } 3 \text {, in three passes, with a } \sim 30 \% \text { reduction ratio each } \\
\text { Wariant } 3 \text {, trzy przepusty z gniotem względnym } \sim 30 \% \text { każdy }\end{array}$} & & \\
\hline 3 & S3 & 42CrMo4 & NANOS-BA ${ }^{\circledR}$ & & \\
\hline
\end{tabular}

1) $690^{\circ} \mathrm{C} / 4 \mathrm{~h}$ and then cooled, together with the furnace, to ambient temperature według wariantu: $690^{\circ} \mathrm{C} / 4 \mathrm{~h}$, z następnym studzeniem w piecu do temperatury otoczenia

2) $940^{\circ} \mathrm{C}$ for 40 minutes and $210^{\circ} \mathrm{C}$ for 120 hours, and finally free cooling in air $\square 950 / 40$ min $+210^{\circ} \mathrm{C} / 120 \mathrm{~h}$, z następnym chłodzeniem swobodnie w powietrzu

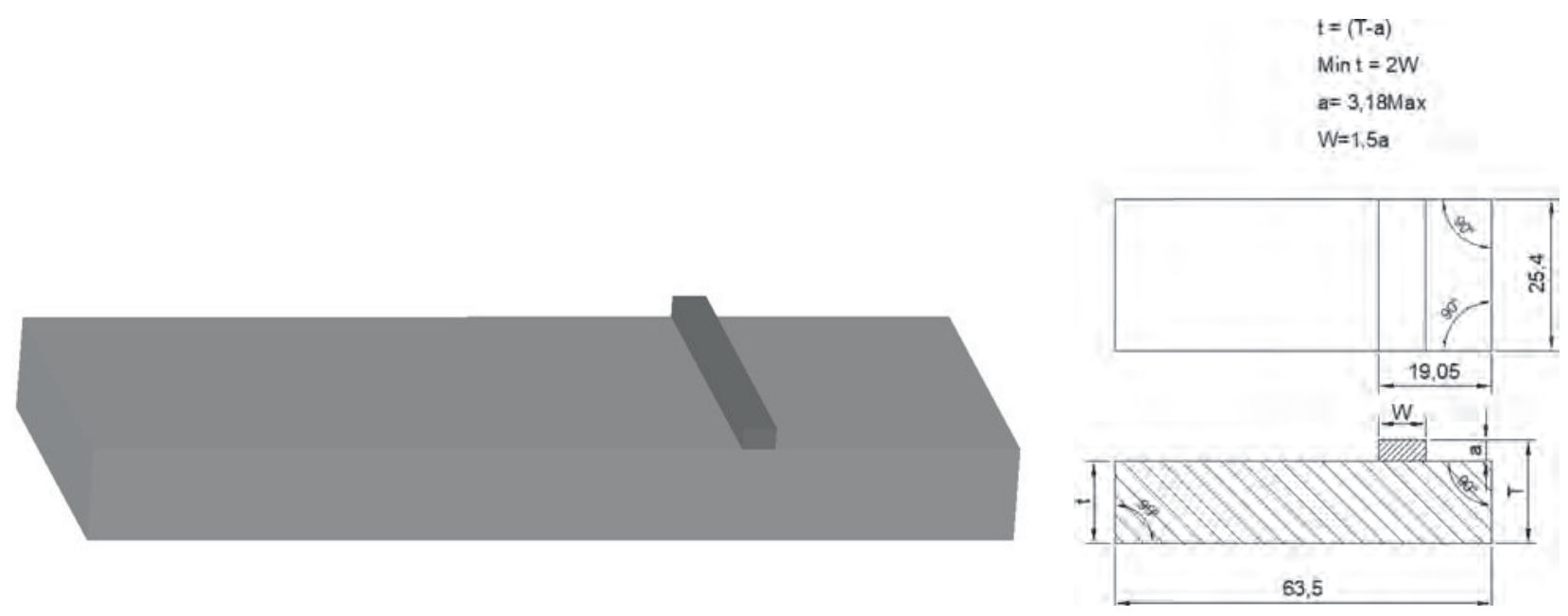

Fig. 1. Diagram of sample for shear strength tests according to the ASTM A264 standard Rys. 1. Schemat próbki do badań wytrzymałości na ścinanie, według normy ASTM A264

The static tensile test at room temperature was carried out in accordance with the PN-EN ISO 6892-1 standard [8]. The shearing tests were carried out in accordance with the guidelines of ASTM A264 [9], the sample production diagram is shown in Figure 1. Microstructural observations were carried out using an OLYMPUS DSX500 light microscope and an Inspect $\mathrm{F}$ scanning electron microscope at magnifications up to $10,000 \times$. The microstructure was observed on samples taken from all clad plates in the state af ter intermediate annealing and after final heat treatment.

\section{TEST RESULTS}

\subsection{PHYSICAL SIMULATIONS OF SEMI-INDUSTRIAL HOT ROLLING}

Based on original experiments $[5,6,11]$, the temperature of the beginning of hot rolling of the 42CrMo4/NANOS-BA clad plates was determined for all variants of plastic processing, which was approximately $1100^{\circ} \mathrm{C}$. The physical simulations were carried out on a reversible roller mill with a $550 \mathrm{~mm}$ diameter of smooth rollers. The measuring system of the rolling mill enables the measurement of power and energy parameters, such as the pressure force of the material on the rollers and the rolling moment.

Figures 2 and 3 show the course of the pressure forces observed during hot rolling of clad plates, according to variants 1 and 3, respectively, while Table 4 presents the force-energy parameters observed during all welding tests. The values of the material pressing forces on the rollers increase with the temperature decrease. The measurement results show that the values of the pressure force in the rolling process are on average from $520 \mathrm{kN}$ to $850 \mathrm{kN}$.

\subsection{BENDING STRENGTH}

The samples taken from clad plates were bent to reach the angle of $180^{\circ}$ and the bending strength was determined on the basis of the force observed during the tests. The deflection angle was measured after unloading. The bending tests for the two-layer samples were performed using 

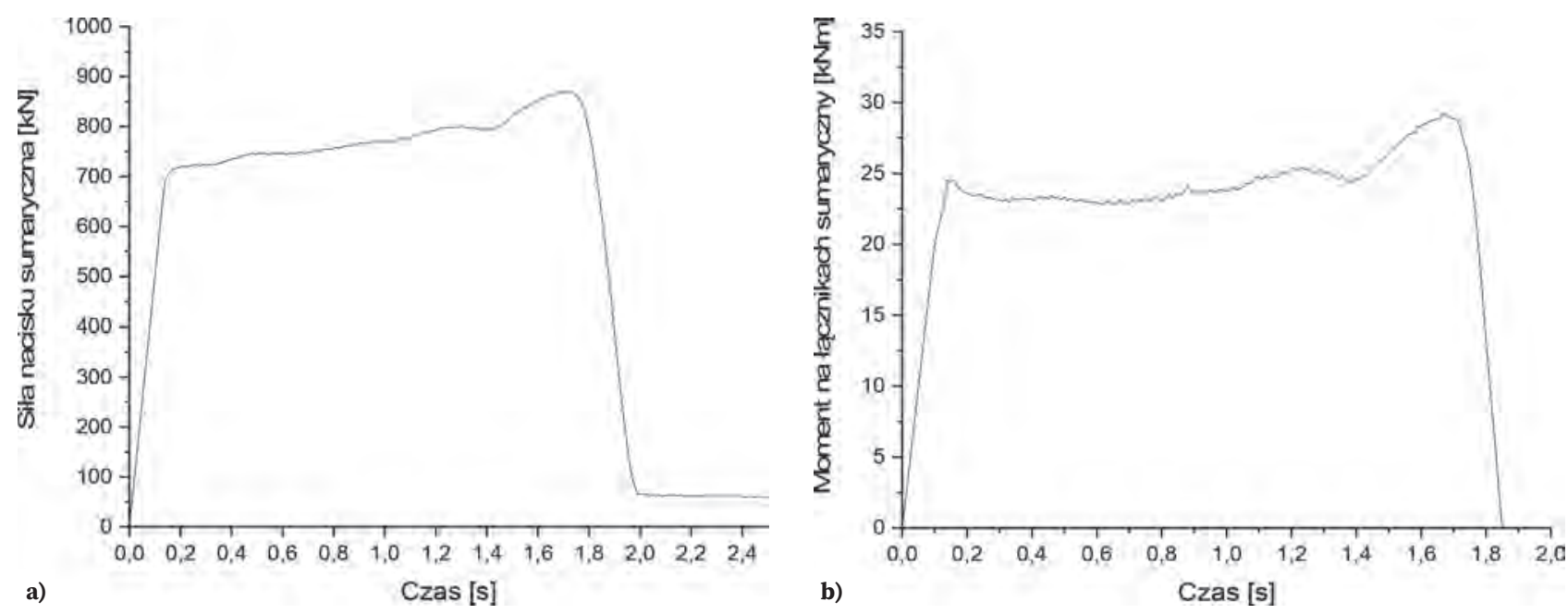

Fig. 2. Diagrams of a) material pressure forces on rollers and b) rolling moment for 42CrMo4/NANOS-BA ${ }^{\circledR}$ clad plates during one pass with a relative draft of $40 \%$ (option 1). Beginning of hot rolling at approximately $1100^{\circ} \mathrm{C}$

Rys. 2. Wykresy przebiegów a) sił nacisku materiału na walce i b) momentu walcowania dla płaskowników platerowanych 42CrMo4/ NANOS-BA ${ }^{\circledR}$ w trakcie jednego przepustu z gniotem względnym $40 \%$ (wariant 1 ). Początek walcowania na gorąco w temperaturze około $1100{ }^{\circ} \mathrm{C}$
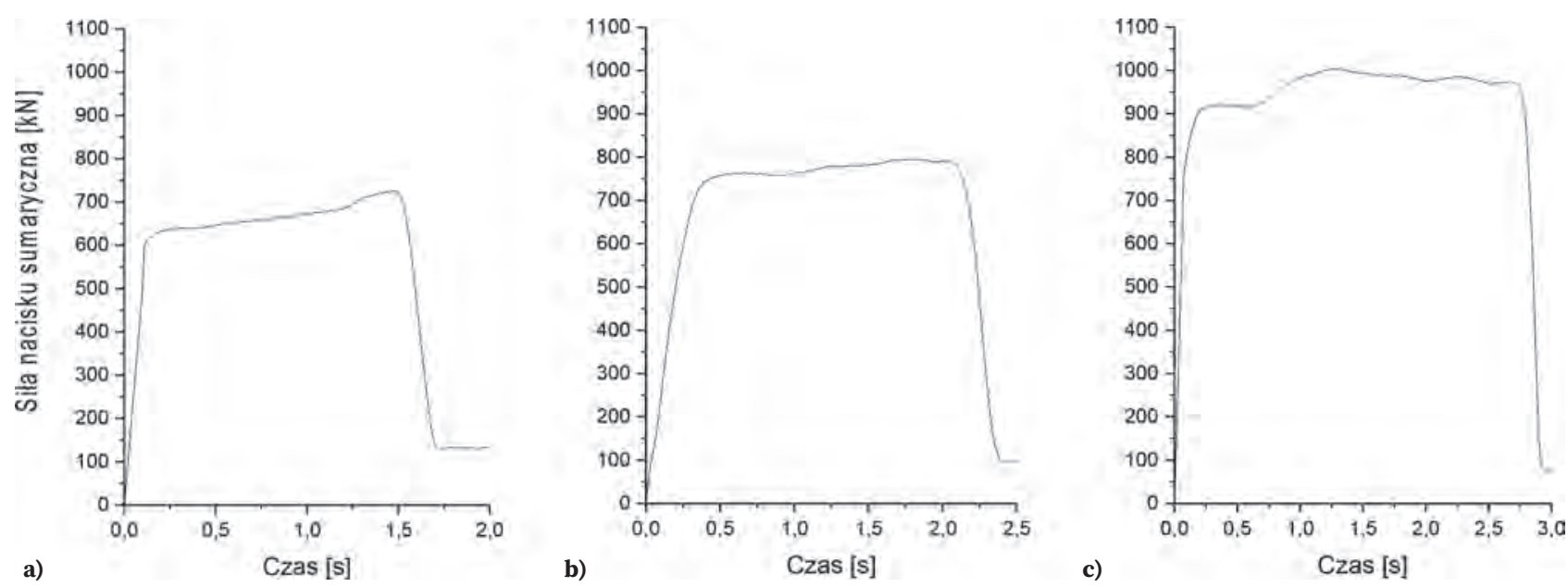

Fig. 3. Diagrams of the course of material pressure forces on the rollers for 42CrMo4/NANOS-BA ${ }^{\circledR}$ clad plates during the: a) first, b) second, and c) third pass, each time performed with a relative draft of $30 \%$ (option 3 )

Rys. 3. Wykresy przebiegów sił nacisku materiału na walce dla płaskowników platerowanych 42CrMo4/NANOS-BA ${ }^{\circledR}$ w trakcie: a) pierwszego, b) drugiego i c) trzeciego przepustu, realizowanego każdorazowo z gniotem względnym 30\% (wariant 3). Początek walcowania na gorąco w temperaturze około $1100^{\circ} \mathrm{C}$

Table 4. Force-energy parameters observed during hot rolling tests of 42CrMo4/NANOS-BA ${ }^{\circledR}$ clad plates, according to three different variants Tabela 4. Parametry siłowo-energetyczne zarejestrowane w trakcie prób walcowania na gorąco płaskowników dwuwarstwowych 42CrMo4/ NANOS-BA ${ }^{\circledR}$, według trzech różnych wariantów

\begin{tabular}{|c|c|c|c|c|c|c|c|}
\hline \multirow{2}{*}{$\begin{array}{c}\text { No. } \\
\text { samples } \\
\text { Oznaczenie } \\
\text { próbek }\end{array}$} & \multirow[t]{2}{*}{$\begin{array}{l}\text { No. pass } \\
\text { Nr } \\
\text { przepustu }\end{array}$} & $\begin{array}{l}\text { force on the } \\
\text { drive side } \\
\text { Siła nacisku od } \\
\text { strony napędu }\end{array}$ & $\begin{array}{c}\text { Force on the } \\
\text { operator's side } \\
\text { Siła nacisku od } \\
\text { strony operatora }\end{array}$ & $\begin{array}{l}\text { Total force } \\
\text { Siła nacisku } \\
\text { całkowita } \\
\end{array}$ & $\begin{array}{l}\text { Moment on the top } \\
\text { connector } \\
\text { Moment na } \\
\text { lączniku górnym }\end{array}$ & $\begin{array}{c}\text { Moment on the } \\
\text { down connector } \\
\text { Moment na } \\
\text { lączniku dolnym }\end{array}$ & $\begin{array}{c}\text { Total moment } \\
\text { of rolling } \\
\text { Moment } \\
\text { całkowity } \\
\end{array}$ \\
\hline & & [MN] & [MN] & [MN] & [kNm] & [kNm] & {$[\mathrm{kNm}]$} \\
\hline \multicolumn{8}{|c|}{ Variant 1 - in one pass, with a $\sim 40 \%$ reduction ratio $\square \mathrm{V}$} \\
\hline S1 & 1 & 0.31 & 0.26 & 0.56 & 10.85 & 11.58 & 22.43 \\
\hline \multicolumn{8}{|c|}{ Variant 2 - in two passes, with a $\sim 30 \%$ reduction ratio each $\square$ Wariant 2 - dwa przepusty, każdy z gniotem względnym $\sim 30 \%$} \\
\hline \multirow{2}{*}{$\mathrm{S} 2$} & 1 & 0.31 & 0.21 & 0.52 & 7.07 & 7.47 & 14.54 \\
\hline & 2 & 0.36 & 0.28 & 0.63 & 18.51 & 20.52 & 39.00 \\
\hline \multicolumn{8}{|c|}{ Variant 3 - in three passes, with a $\sim 30 \%$ reduction ratio each $n$ Wariant 3 - trzy przepusty, każdy z gniotem względnym $\sim 30 \%$} \\
\hline \multirow{3}{*}{ S3 } & 1 & 0.29 & 0.23 & 0.52 & 6.34 & 7.38 & 13.72 \\
\hline & 2 & 0.38 & 0.25 & 0.62 & 18.61 & 20.89 & 39.50 \\
\hline & 3 & 0.48 & 0.37 & 0.85 & 25.53 & 28.62 & 54.15 \\
\hline
\end{tabular}


Table 5. Results after bending test of samples taken from clad plates after additional isothermal annealing

Tabela 5. Wyniki prób zginania próbek pobranych z płaskowników platerowanych po dodatkowym wyżarzaniu izotermicznym

\begin{tabular}{|c|c|c|c|c|}
\hline \multirow{2}{*}{$\begin{array}{l}\text { No. } \\
\text { clad plate } \\
\text { Nr } \\
\text { płaskownika }\end{array}$} & \multirow{2}{*}{$\begin{array}{c}\text { Basic layer/cladding } \\
\text { layer } \\
\text { Warstwa podstawowa/ } \\
\text { warstwa nakładana }\end{array}$} & $\begin{array}{c}\text { Bending strength } \\
\text { Wytrzymałość na } \\
\text { zginanie }\end{array}$ & $\begin{array}{l}\text { Deflection angle } \\
\text { Kąt ugięcia }\end{array}$ & \multirow[t]{2}{*}{$\begin{array}{l}\text { Results of bending tests to } 180^{\circ} \text { angle } \\
\text { Wyniki próby zginania do kąta } 180^{\circ}\end{array}$} \\
\hline & & $R_{\mathrm{g}},[\mathrm{MPa}]$ & {$\left[{ }^{\circ}\right]$} & \\
\hline \multicolumn{5}{|c|}{$\begin{array}{l}\text { After one pass, with a } \sim 40 \% \text { reduction ratio and two stages heat treatment } \\
\text { Po jednym przepuście z gniotem względnym } \sim 40 \% \text { i dwuetapowej obróbce cieplnej }\end{array}$} \\
\hline \multirow{2}{*}{ S1 } & 42CrMo4/NANOS-BA ${ }^{\circledast}$ & 175 & 135 & positive $\mathbf{p}$ pozytywny \\
\hline & NANOS-BA ${ }^{\circledast} / 42 \mathrm{CrMo} 4$ & 195 & 137 & positive $\square$ pozytywny \\
\hline \multicolumn{5}{|c|}{$\begin{array}{l}\text { After two passes, with a } \sim 30 \% \text { reduction ratio each and two stages heat treatment } \\
\text { Po dwóch przepustach, każdy z gniotem względnym } \sim 30 \% \text { i dwuetapowej obróbce cieplnej }\end{array}$} \\
\hline \multirow{2}{*}{$\mathrm{S} 2$} & 42CrMo4/NANOS-BA ${ }^{\circledast}$ & 301 & 164 & positive $\square$ pozytywny \\
\hline & NANOS-BA ${ }^{\circledast} / 42 \mathrm{CrMo} 4$ & 113 & 49 & negative/fracture negatywny/pęknięcie \\
\hline \multicolumn{5}{|c|}{$\begin{array}{l}\text { After three passes, with a } \sim 30 \% \text { reduction ratio and two stages heat treatment } \\
\text { Po trzech przepustach, każdy z gniotem względnym } \sim 30 \% \text { i dwuetapowej obróbce cieplnej }\end{array}$} \\
\hline \multirow{2}{*}{ S3 } & 42CrMo4/NANOS-BA ${ }^{\circledast}$ & 212 & 153 & positive pozytywny \\
\hline & NANOS-BA ${ }^{\circledast} / 42 \mathrm{CrMo} 4$ & 139 & 44 & negative/fracture ${ }^{-}$negatywny/pęknięcie \\
\hline
\end{tabular}

a punch pressure from the side of the $42 \mathrm{CrMo} 4$ steel layer and the reverse side of the NANOS-BA ${ }^{\circledR}$ steel. The test results are shown in Table 5 . For samples taken from clad plates No. S1, S2, and S3 after additional heat treatment, a deflection angle of $180^{\circ}$ was obtained for all samples subjected to the bend test with a punch pressure from the side of the NANOS-BA ${ }^{\circledR}$ layer. The highest bending strength in this arrangement of layers, amounting to $301 \mathrm{MPa}$, was obtained for clad plate No. S2. In the case of the pressure of the punch from the 42CrMo4 layer side, the deflection angle of $180^{\circ}$ was obtained only for sample S1. The bending strength in this configuration of the layer arrangement for this variant was $195 \mathrm{MPa}$. Sample photographs of samples after the tests are shown in Figure 4.

\subsection{TENSILE STRENGTH}

The mechanical properties of the experimental welds of $42 \mathrm{CrMo} 4$ and NANOS-BA ${ }^{\circledR}$ steels determined in the static tensile test are presented in Table 6. Sample photographs of samples after tensile tests are shown in Figure 5. On the basis of the obtained results, an upward trend in the values of mechanical properties $R_{\mathrm{p} 0.2}, R_{\mathrm{m}}$ and $A$ was observed for 42CrMo4/NANOS-BA ${ }^{\circledR}$ clad plates along with an increase in the value of total draft during hot rolling with additional heat treatment. This is due to different diffusion mechanisms occurring during the joining of materials under the influence of pressure exerted on the surfaces, in each of the three different variants, and diffusion phenomena occurring in the joined surface during their heat treatment.

\subsection{SHEAR STRENGTH}

The list of the results of the shear strength tests is presented in Table 7, while the photographs of the samples after the test are shown in Figure 6. As a result of the performed tests, an increasing tendency of the shear strength of $42 \mathrm{CrMo} 4 / \mathrm{NANOS}-\mathrm{BA}^{\circ}$ clad plates was observed, as a result of the use of increasingly higher total draft values during the welding of layers in the hot rolling process.

\subsection{MICROSCOPIC TESTS}

The structure was observed using an Olympus DSX500 light microscope and an Inspect F scanning electron microscope (SEM). No visible, distinct joined surface was found in the examined magnification range as a result of observations of the non-etched microsections from 42CrMo4/

Table 6. Results of mechanical properties, determined in a static tensile test of the obtained 42CrMo4/NANOS-BA ${ }^{\circledR}$ clad plates after final isothermal annealing

Tabela 6. Wyznaczone w statycznej próbie rozciagania właściwości mechaniczne płaskowników platerowanych 42CrMo4/NANOS-BA ${ }^{\circledR}$ po końcowym wyżarzaniu izotermicznym

\begin{tabular}{|c|c|c|c|c|}
\hline $\begin{array}{l}\text { No. } \\
\text { Lp. }\end{array}$ & $\begin{array}{l}\text { Basic layer/cladding layer } \\
\text { Warstwa podstawowa/warstwa nakładana }\end{array}$ & $R_{\mathrm{p} 0,2},[\mathrm{MPa}]$ & $R_{\mathrm{m}},[\mathrm{MPa}]$ & $A,[\%]$ \\
\hline \multicolumn{5}{|c|}{$\begin{array}{l}\text { After one pass, with a } \sim 40 \% \text { reduction ratio and two stages heat treatment } \\
\text { Po jednym przepuście z gniotem względnym } \sim 40 \% \text { i dwuetapowej obróbce cieplnej }\end{array}$} \\
\hline 1 & 42CrMo4/NANOS-BA ${ }^{\circledR}$ (S1) & 935 & 1428 & 6.9 \\
\hline \multicolumn{5}{|c|}{$\begin{array}{l}\text { After two passes, with a 30\% reduction ratio each and two stages heat treatment } \\
\text { Po dwóch przepustach, każdy z gniotem względnym } \sim 30 \% \text { i dwuetapowej obróbce cieplnej }\end{array}$} \\
\hline 2 & 42CrMo4/NANOS-BA ${ }^{\circledR}$ (S2) & 983 & 1484 & 8.8 \\
\hline \multicolumn{5}{|c|}{$\begin{array}{l}\text { After three passes, with a 30\% reduction ratio and two stages heat treatment } \\
\text { Po trzech przepustach, każdy z gniotem względnym } \sim 30 \% \text { i dwuetapowej obróbce cieplnej }\end{array}$} \\
\hline 3 & 42CrMo4/NANOS-BA ${ }^{\circledR}$ (S3) & 1036 & 1504 & 10.9 \\
\hline
\end{tabular}




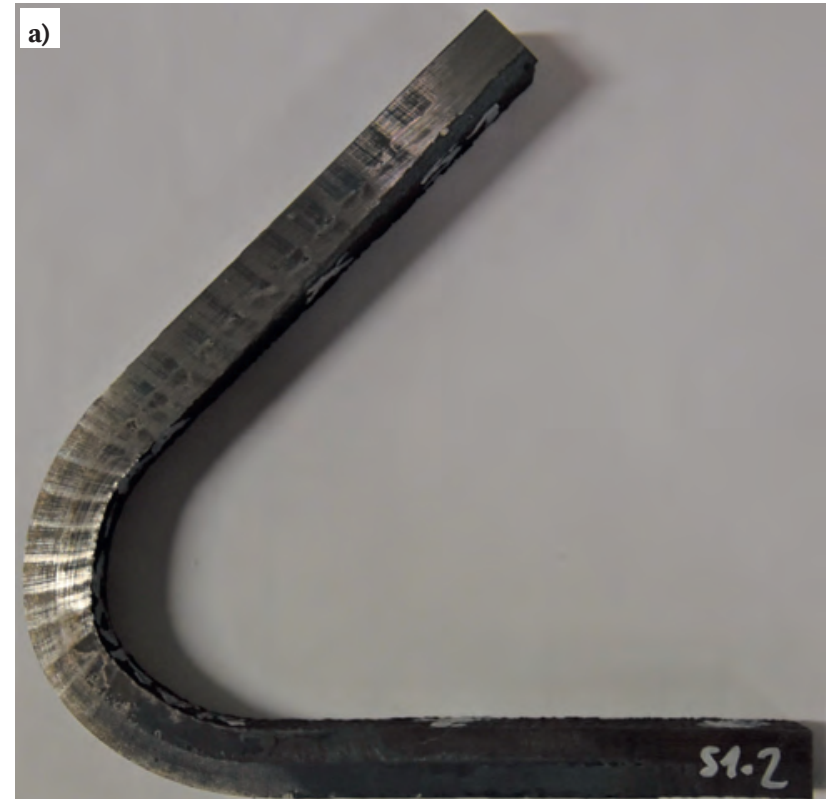

Sample S1: 42CrMo4/NANOS-BA ${ }^{\circledast}$

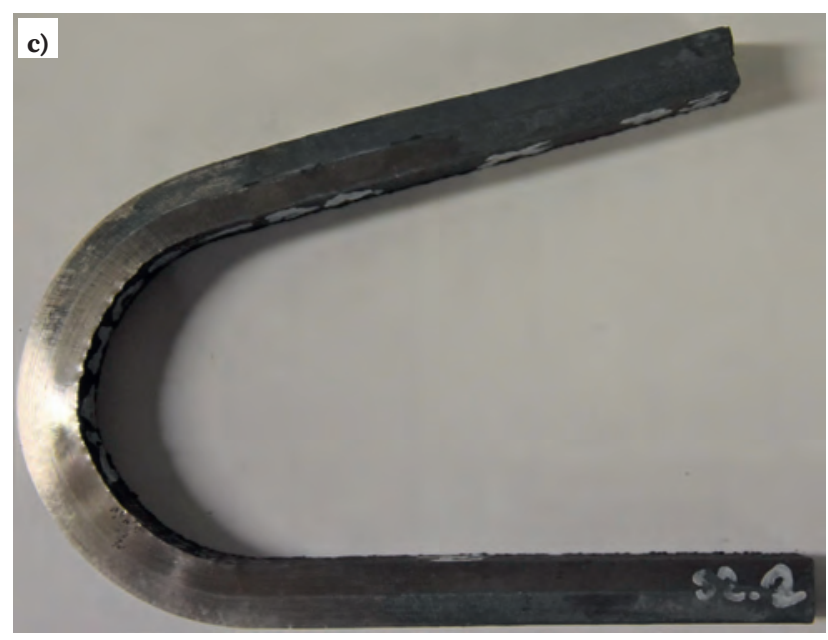

Sample S2: 42CrMo4/NANOS-BA ${ }^{\oplus}$

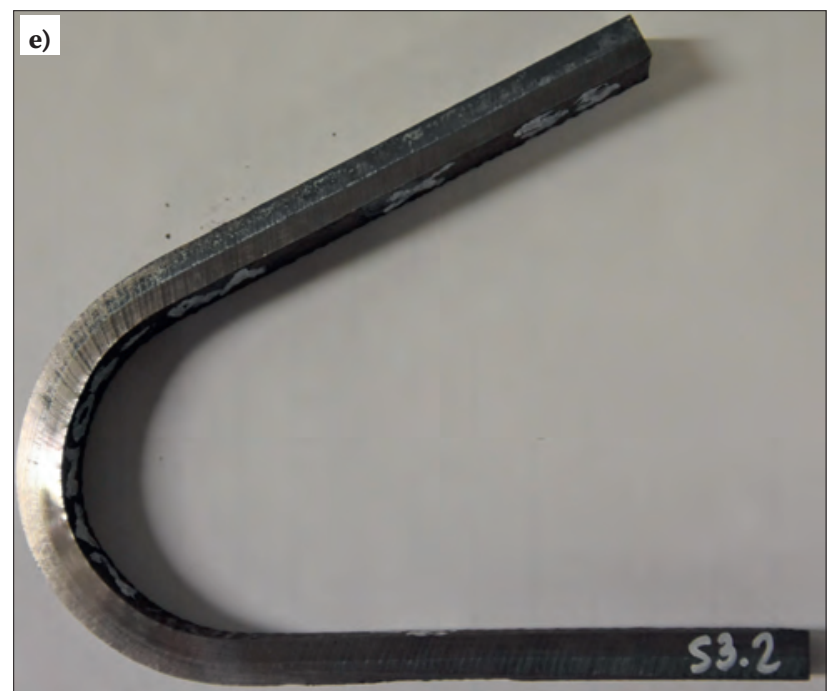

Sample S3: 42CrMo4/NANOS-BA ${ }^{\circledR}$

Fig. 4. Sample photographs after a two-sided bending test of samples taken from S1-S3 clad plates, arrangement of layers a), c), e) 42CrMo4/NANOS-BA ${ }^{\oplus}$, b), d), f) NANOS-BA $/ 42$ CrMo4

Rys. 4. Przykładowe fotografie zginanych dwustronnie próbek pobranych z płaskowników platerowanych S1-S3, ułożenie warstw a), c), e) 42CrMo4/NANOS-BA ${ }^{\oplus}$, b), d), f) NANOS-BA®/42CrMo4

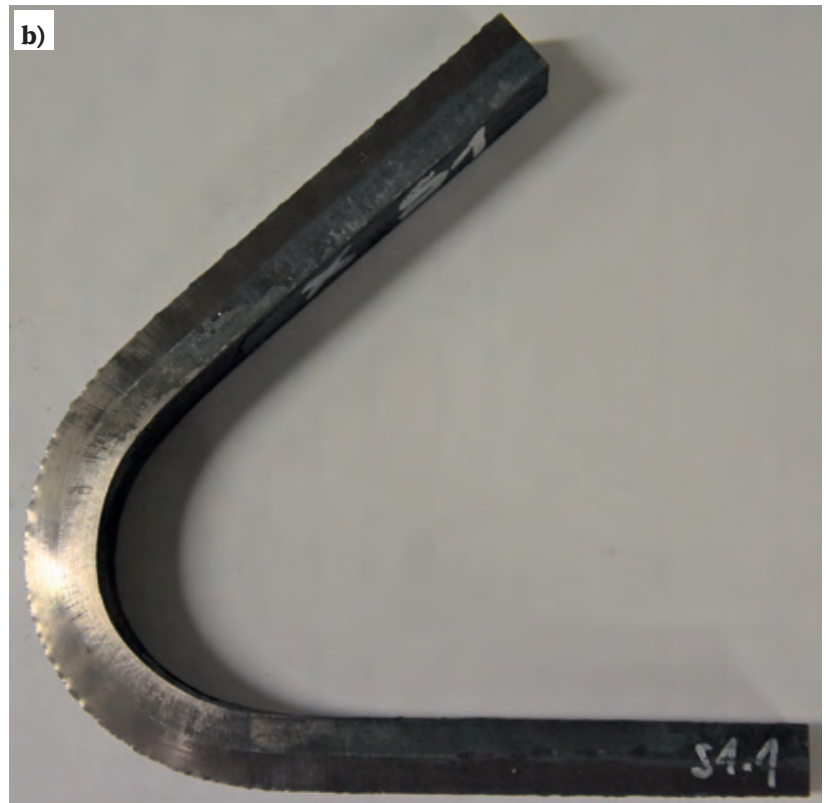

Sample S1: NANOS-BA ${ }^{\circledast}$ /42CrMo4

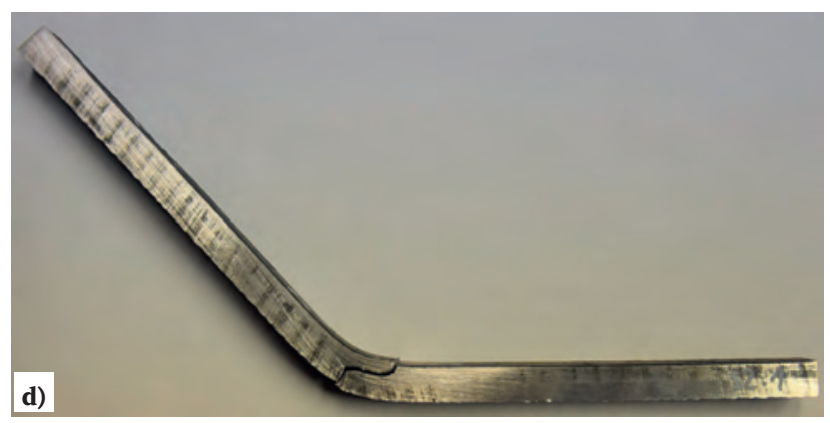

Sample S2: NANOS-BA / 42CrMo4

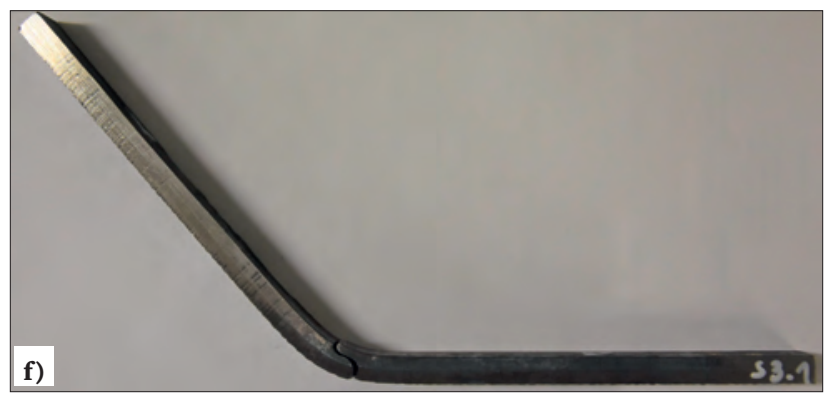

Sample S3: NANOS-BA®/ 42CrMo4 

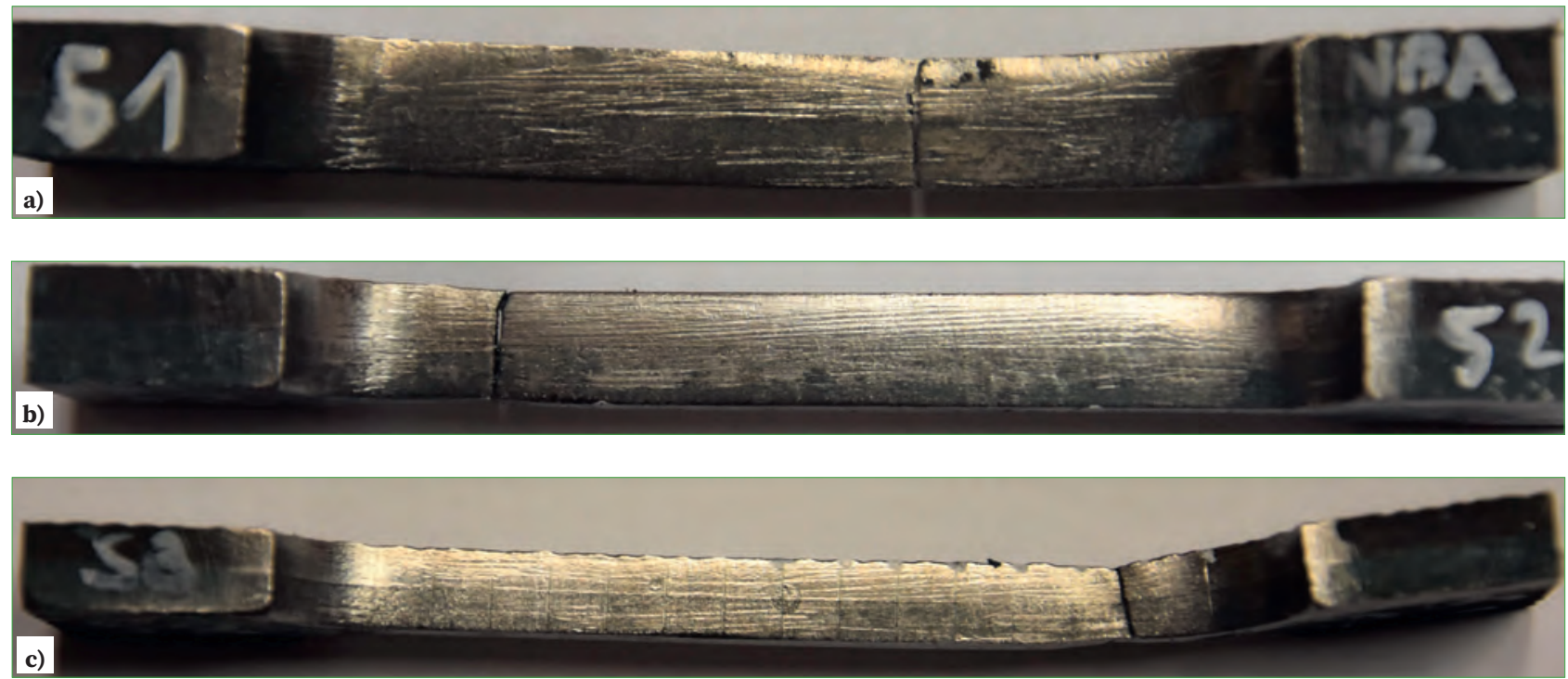

Fig. 5. Sample photographs of strength samples after tensile test at room temperature. The samples were taken from 42CrMo4/NANOS-BA ${ }^{\oplus}$ clad plates (basic layer - 42CrMo4; cladding layer - NANOS-BA ${ }^{\oplus}$ ), after three different variants of hot rolling: one pass, with a $\sim 40 \%$ reduction ratio (a), two passes, with a $\sim 30 \%$ reduction ratio (b), three passes, with a $\sim 30 \%$ reduction ratio (c) and two-stage heat treatment: 1 ) intermediate annealing and 2) isothermal annealing: $210^{\circ} \mathrm{C} / 120 \mathrm{~h}$

Rys. 5. Przykładowe fotografie próbek wytrzymałościowych po próbie rozciagania w temperaturze pokojowej. Próbki pobrano z płaskowników platerowanych 42CrMo4/NANOS-BA ${ }^{\circledast}$ (warstwa podstawowa - 42CrMo4; warstwa nakładana - NANOS-BA ${ }^{\circledR}$ ), po trzech różnych wariantach walcowania na gorąco: jeden przepust z gniotem względnym $\sim 40 \%$ (a), dwa przepusty, każdy z gniotem względnym $\sim 30 \%$ (b), trzy przepusty, każdy z gniotem względnym $\sim 30 \%$ (c) i dwuetapowej obróbce cieplnej: 1) wyżarzaniu międzyoperacyjnym i 2) wyżarzaniu izotermicznym: $210^{\circ} \mathrm{C} / 120 \mathrm{~h}$

a)
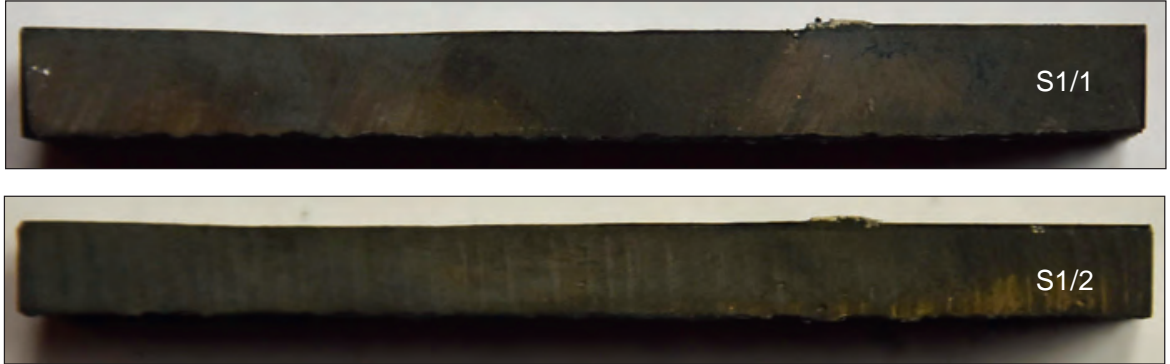

b)
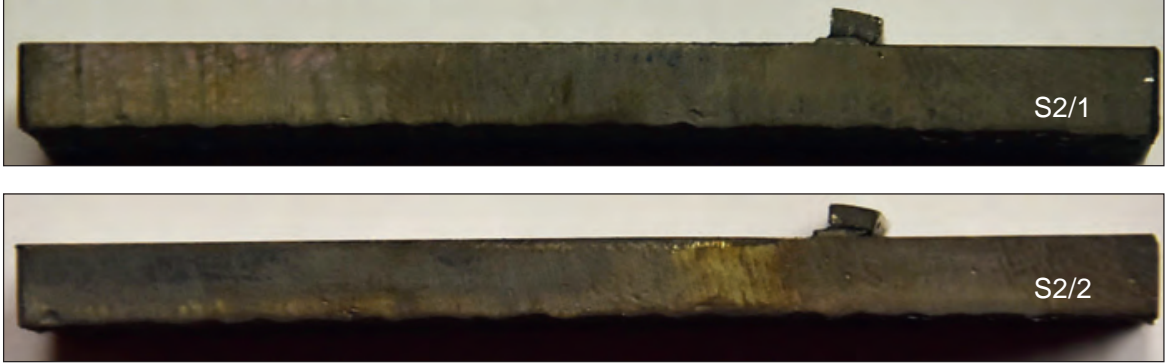

c)
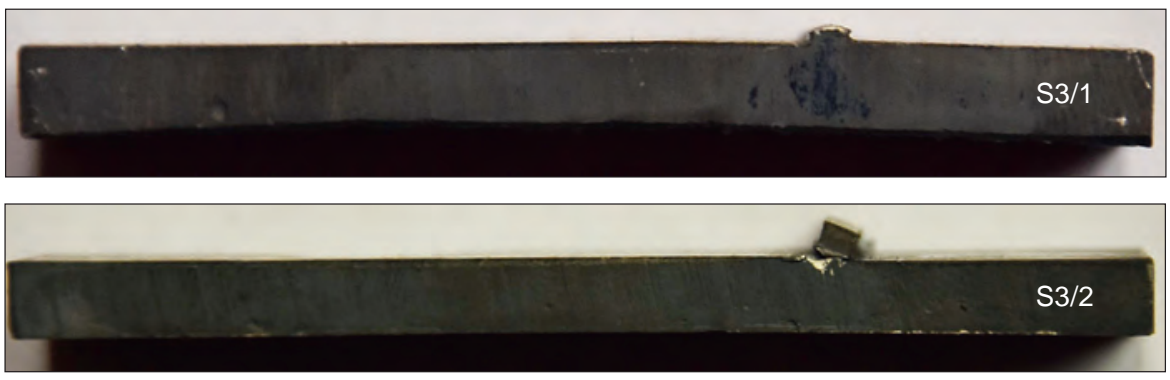

Fig. 6. Sample photographs of strength samples after shear test at room temperature. The samples were taken from 42CrMo4/NANOS-BA clad plates, after three different variants of hot rolling: a) variant 1, b) variant 2, c) variant 3 and two-stage heat treatment: 1) intermediate annealing and 2) isothermal annealing: $210^{\circ} \mathrm{C} / 120 \mathrm{~h}$

Rys. 6. Przykładowe fotografie próbek wytrzymałościowych po próbie ścinania w temperaturze pokojowej. Próbki pobrano z płaskowników platerowanych 42CrMo4/NANOS-BA ${ }^{\circledR}$, po trzech różnych wariantach walcowania na gorąco: a) wariant 1, b) wariant 2 , c) wariant 3 i dwuetapowej obróbce cieplnej: wyżarzaniu międzyoperacyjnym $\mathrm{i}$ wyżarzaniu izotermicznym: $210^{\circ} \mathrm{C} / 120$ 
Table 7. Results of shear test, according to the ASTM A264 standard, of 42CrMo4/NANOS-BA ${ }^{\circledR}$ clad plates after additional isothermal annealing Tabela 7. Wyniki próby ścinania, według normy ASTM A264, płaskowników platerowanych 42CrMo4/NANOS-BA ${ }^{\circledR}$ w stanie po dodatkowym wyżarzaniu izotermicznym

\begin{tabular}{|c|c|c|}
\hline \multirow{2}{*}{$\begin{array}{l}\text { No. } \\
\text { Lp. }\end{array}$} & \multirow{2}{*}{$\begin{array}{l}\text { Basic layer/ cladding layer } \\
\text { Warstwa podstawowa/warstwa nakładana }\end{array}$} & Shear strength $\square$ Wytrzymałość na ścinanie \\
\hline & & $R_{\mathrm{t}}$, [MPa] \\
\hline \multicolumn{3}{|c|}{$\begin{array}{l}\text { After one pass, with a } 40 \% \text { reduction ratio and two stages heat treatment } \\
\text { Po jednym przepuście z gniotem względnym } \sim 40 \% \text { i dwuetapowej obróbce cieplnej }\end{array}$} \\
\hline 1 & 42CrMo4/NANOS-BA ${ }^{\circledast}$ & 639 \\
\hline \multicolumn{3}{|c|}{$\begin{array}{l}\text { After two passes, with a } 30 \% \text { reduction ratio each and two stages heat treatment } \\
\text { Po dwóch przepustach, każdy z gniotem względnym } \sim 30 \% \text { i dwuetapowej obróbce cieplnej }\end{array}$} \\
\hline 2 & 42CrMo4/NANOS-BA & 625 \\
\hline \multicolumn{3}{|c|}{$\begin{array}{l}\text { After three passes, with a 30\% reduction ratio and two stages heat treatment } \\
\text { Po trzech przepustach, każdy z gniotem względnym } \sim 30 \% \text { i dwuetapowej obróbce cieplnej }\end{array}$} \\
\hline 3 & 42CrMo4/NANOS-BA ${ }^{\circledast}$ & 761 \\
\hline
\end{tabular}

Table 8. Microphotography of clad plates within the joined surface. The samples were taken from 42CrMo4/NANOS-BA ${ }^{\circledR}$ clad plates after hot rolling, according to variants 1-3, and two-stage heat treatment, MS, longitudinal microsection, non-etched

Tabela 8. Mikrofotografia płaskowników platerowanych w obszarze linii zgrzewania. Próbki pobrano z płaskowników platerowanych 42CrMo4/NANOS-BA ${ }^{\circledast}$ w stanie po walcowaniu na gorąco, według wariantów 1-3 i dwuetapowej obróbce cieplnej, MS, zgład wzdłużny, nietrawiony

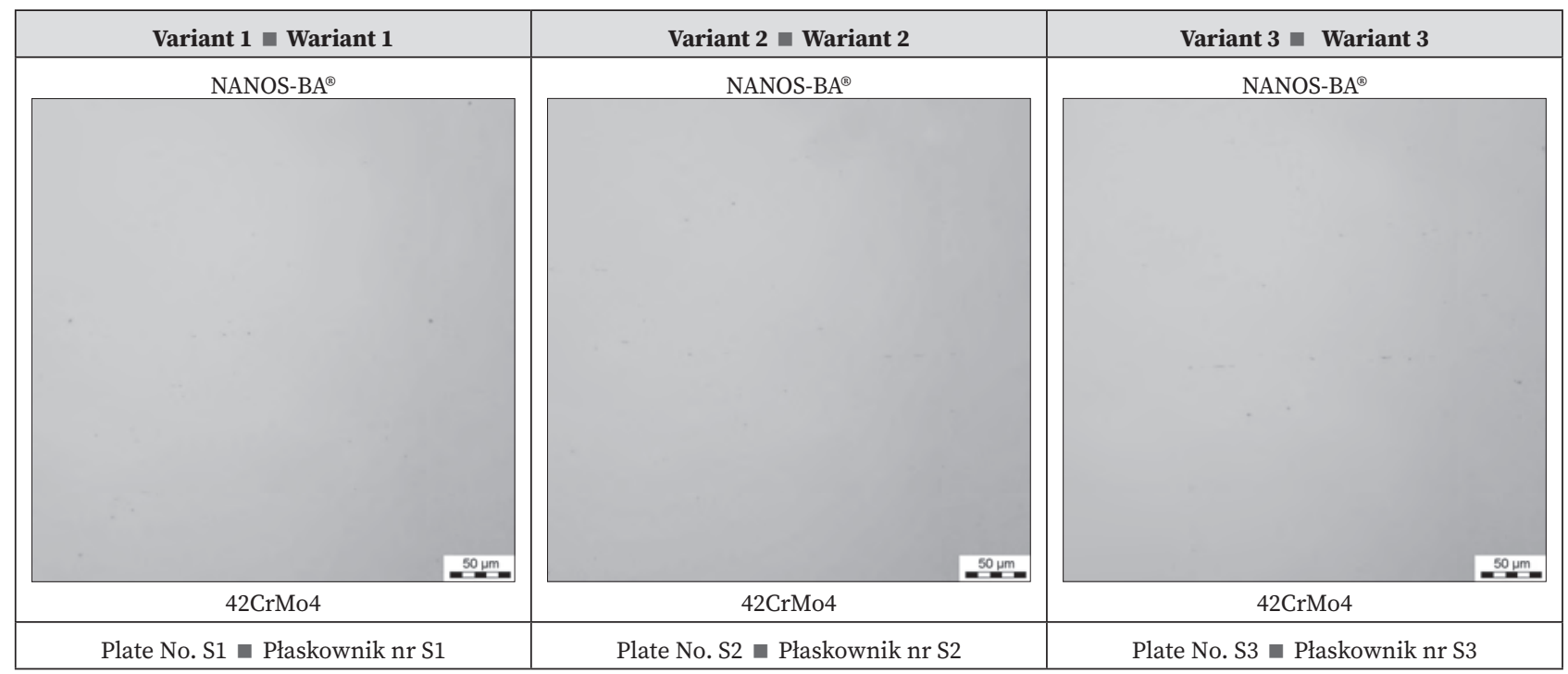

Table 9. Microstructure of clad plates within the joined surface. The samples were taken from 42CrMo4/NANOS-BA ${ }^{\oplus}$ clad plates after hot rolling, according to variants 1-3, and two-stage heat treatment, MS, longitudinal microsection, etched with Nital

Tabela 9. Mikrostruktura płaskowników platerowanych ze stali 42CrMo4/NANOS-BA ${ }^{\circledast}$ w obszarze linii zgrzewania. Próbki pobrano z płaskowników w stanie po walcowaniu na gorąco, według wariantów 1-3 i dwuetapowej obróbce cieplnej, MS, zgład wzdłużny, trawiony Nitalem

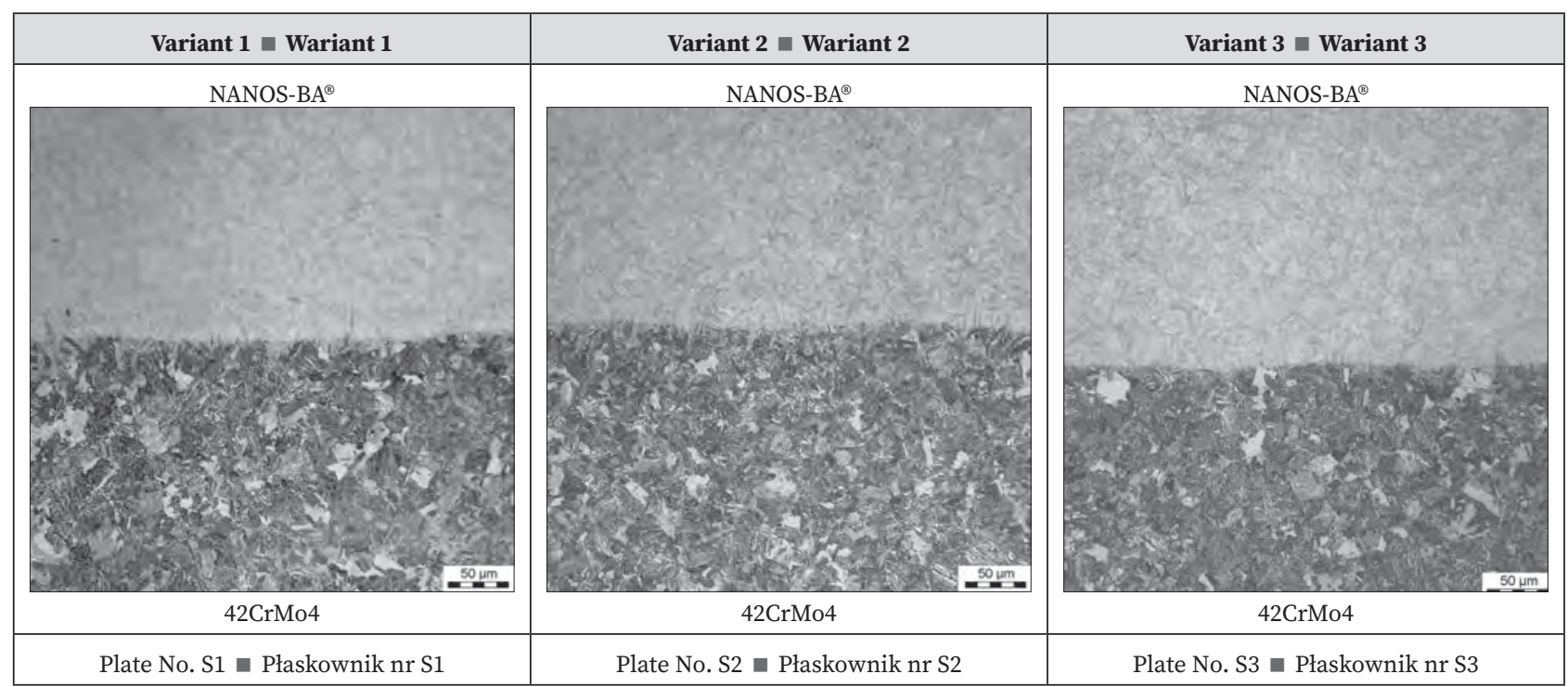


NANOS-BA ${ }^{\circledast}$ clad plates carried out using a light microscope. No cracks or other internal discontinuities were found in the area of the welding plane. This indicates the possibility of obtaining good-quality material combinations as a result of the rolling method used. Table 8 presents microphotographs taken in the welding area of the 42CrMo4 and NANOS-BA ${ }^{\circledR}$ steel layers after hot rolling and two-stage heat treatment. Table 9 presents photographs of samples taken from the same clad plates after etching with nital. Figures 7-9 show photographs of the microstructure of the S1, S2 and S3 clad plates in the welding area, taken with the use of a scanning electron microscope (SEM). The microstructure of NANOS-BA ${ }^{\circledast}$ steel is a two-phase structure, consisting of carbide-free lower bainite and residual austenite, characteristic for this steel grade after final isothermal annealing according to parameters $210^{\circ} \mathrm{C} / 120 \mathrm{~h}$. A multiphase microstructure was observed in the $42 \mathrm{CrMo} 4$ steel layer, consisting of a mixture of upper bainite and acicular ferrite, with a small proportion of pearlite.

\section{SUMMARY}

As a result of the technology proposed in the study for welding layers of non-weldable steel grades $42 \mathrm{CrMo} 4$ and NANOS-BA ${ }^{\circledast}$ in the hot rolling process, according to three different variants, clad plates obtained without macroscop-

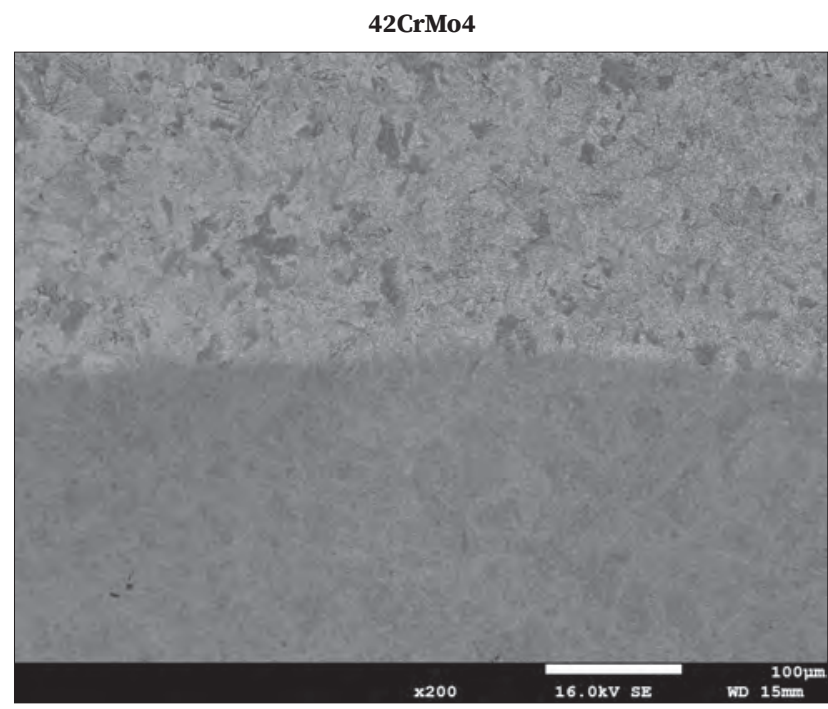

NANOS-BA ${ }^{\oplus}$

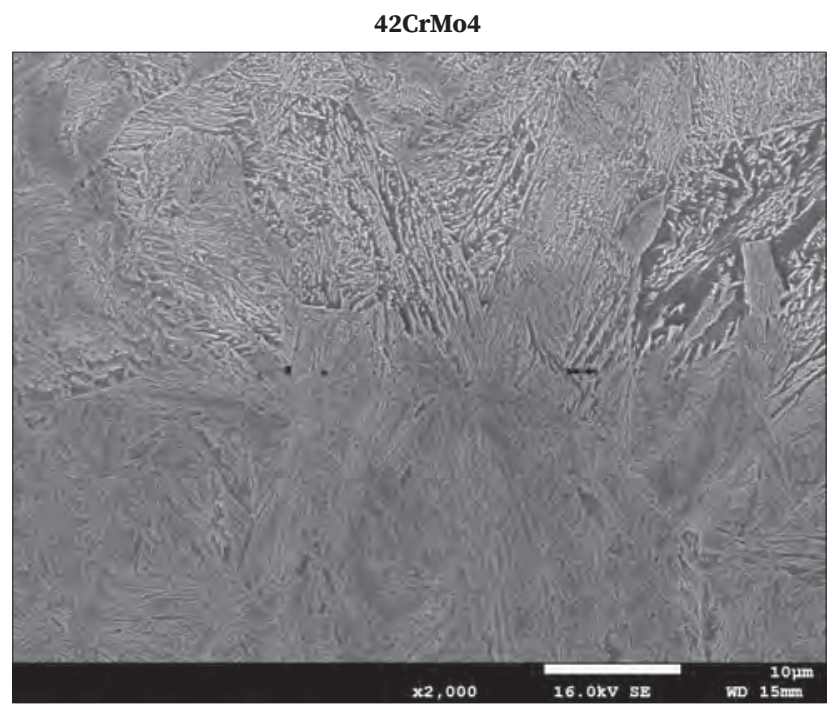

NANOS-BA

Fig. 7. Microstructure of the $42 \mathrm{CrMo}$ /NANOS-BA ${ }^{\circledast}$ clad plate No. S1, after hot rolling, in accordance with variant 1 and two-stage heat treatment. Joined surface, longitudinal microsection, SEM

Rys. 7 Mikrostruktura płaskownika platerowanego 42CrMo4/NANOS-BA ${ }^{\circledR}$ nr S1, w stanie po walcowaniu na gorąco, zgodnie z wariantem 1 i dwuetapowej obróbce cieplnej. Płaszczyzna zgrzewania, zgład wzdłużny, SEM

42CrMo4

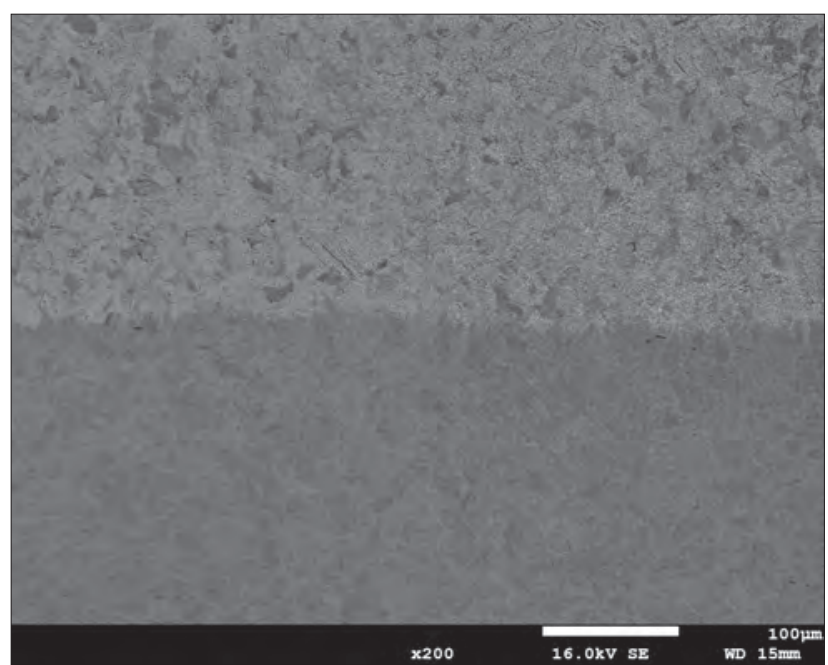

NANOS-BA ${ }^{\circledR}$
42CrMo4

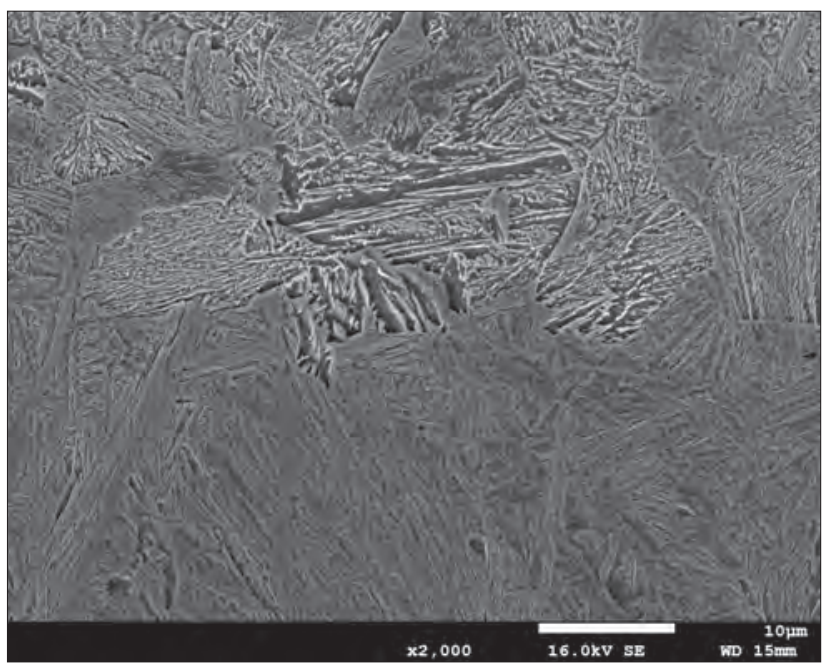

NANOS-BA

Fig. 8. Microstructure of the 42CrMo4/NANOS-BA ${ }^{\circledR}$ clad plate No. S2, after hot rolling, in accordance with variant 1 and two-stage heat treatment. Joined surface, longitudinal microsection, SEM

Rys. 8. Mikrostruktura płaskownika platerowanego $42 \mathrm{CrMo} 4 / \mathrm{NANOS}-\mathrm{BA}^{\circledR} \mathrm{nr}$ S2, w stanie po walcowaniu na gorąco, zgodnie $\mathrm{z}$ wariantem 1 i dwuetapowej obróbce cieplnej. Płaszczyzna zgrzewania, zgład wzdłużny, SEM 


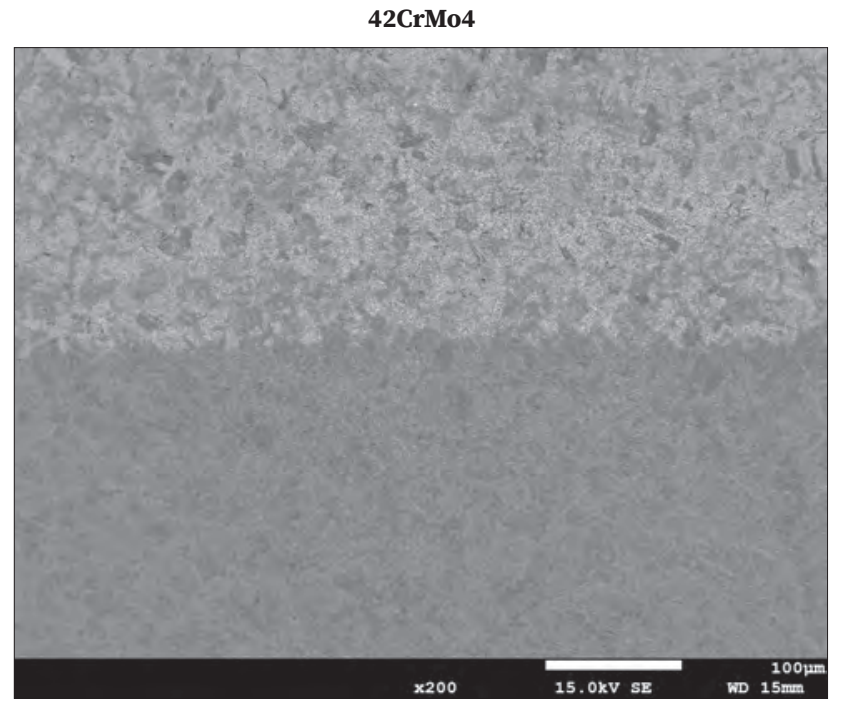

NANOS-BA ${ }^{\oplus}$

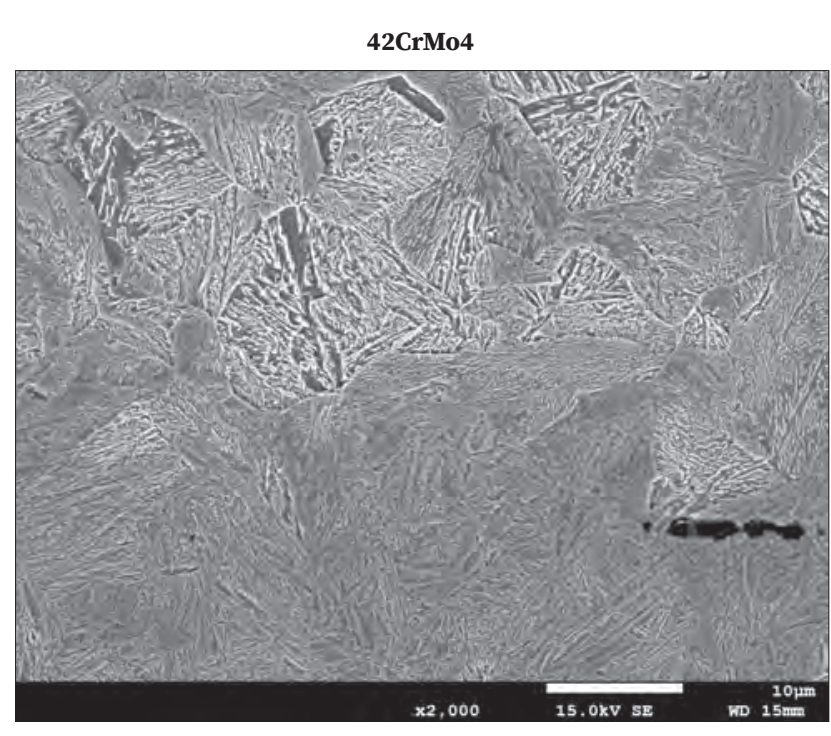

NANOS-BA ${ }^{\circledast}$

Fig. 9. Microstructure of the 42CrMo4/NANOS-BA ${ }^{\oplus}$ clad plate No. S3, after hot rolling, in accordance with variant 1 and two-stage heat treatment. Joined surface, longitudinal microsection, SEM

Rys. 9. Mikrostruktura płaskownika platerowanego $42 \mathrm{CrMo4} / \mathrm{NANOS}-\mathrm{BA}{ }^{\circledR}$ nr S3, w stanie po walcowaniu na gorąco, zgodnie z wariantem 1 i dwuetapowej obróbce cieplnej. Płaszczyzna zgrzewania, zgład wzdłużny, SEM

ically visible cracks and delamination, which proves that the process parameters were selected correctly. The results of laboratory tests carried out on samples taken from the 42CrMo4/NANOS-BA ${ }^{\circledast}$ clad plates prove that in the process of hot rolling and two-stage heat treatment, it is possible to obtain a permanent bond between the layers of $42 \mathrm{CrMo} 4$ and NANOS-BA ${ }^{\circledR}$ steels. The microscopic observations con- firmed the high quality of welding of the produced clad plates was confirmed. By applying additional heat treatment with isothermal transformation of NANOS-BA ${ }^{\circledast}$ steel layers into nano-structured bainite, high mechanical properties were obtained for all macrocomposite clad plates made of 42CrMo4/NANOS-BA ${ }^{\circledast}$ steel.

\section{REFERENCES}

[1] G.M. Grigorenko, W.A. Kostin. Spawalność stali i kryteria jej oceny. Przeglad Spawalnictwa, 2013, 7, p. 11-17.

[2] B. Garbarz, W. Burian, J. Marcisz, A. Wiśniewski. The Nano-Duplex NANOS-BA Steel for Application in Construction of Armours. Problems of Mechatronics Armament, Aviation, Safety Engineering, 2012, 4 (10), p. 7-22.

[3] B. Walnik, J. Marcisz, A. Iwaniak, J. Wieczorek. Badania zużycia ściernego nanostrukturalnej stali bainitycznej. Prace Instytutu Metalurgii Żelaza, 2017, 69 (3), p. 55-60.

[4] J. Marcisz, W. Burian, B. Walnik. Opracowanie założeń technicznych projektu lekkiego opancerzenia na bazie perforowanych blach ze stali o wytrzymałości powyżej $2 \mathrm{GPa}$, spełniającego wymagania 2 i 3 poziomu ochrony wg STANAG 4569. Prace Instytutu Metalurgii Żelaza, 2017, 69 (3), p. 80-83.

[5] B. Walnik, D. Woźniak, M. Adamczyk. A. Żak. Opracowanie technologii wytwarzania ptaskowników warstwowych taczonych metoda walcowania na goraco i badania eksperymentalnych wyrobów. Częśc I. Sprawozdanie z pracy badawczej IMŻ no. S0 0972, 2018. [unpublished].

[6] B. Walnik, D. Woźniak, M. Adamczyk. A. Żak. Opracowanie technologii wytwarzania ptaskowników warstwowych łaczonych metoda walcowania na goraco i badania eksperymentalnych wyrobów. Część II. Sprawozdanie z pracy badawczej IMŻ no. S0 0972, 2019. [unpublished].

[7] Polski Komitet Normalizacyjny. PN-EN ISO 7438:2021-04. Metale Próba zginania. Warszawa: PKN, 2021.

[8] Polski Komitet Normalizacyjny. PN-EN ISO 6892-1:2020-05. Metale - Próba rozciagania - Czesść 1: Metoda badania $w$ temperaturze pokojowej. Warszawa: PKN, 2020.

[9] ASTM International, ASTM A264 - 03: Standard Specification for Stainless Chromium-Nickel Steel-Clad Plate. West Conshohocken: PA, 2003.

[10] B. Walnik, D. Woźniak, M. Adamczyk. Badania właściwości mechanicznych i mikrostruktury eksperymentalnych blach warstwowych walcowanych na gorąco. Hutnik - Wiadomości Hutnicze, 2019, 86 (10), p. 309-314.

[11] B. Walnik, D. Woźniak, M. Adamczyk, A. Nieszporek. Opracowanie technologii wytwarzania plaskowników makrokompozytowych, ztożonych $z$ warstw ze stali nanostrukturalnej o ultra wysokiej wytrzymałości $w$ procesie walcowania na goraco. Sprawozdanie z pracy badawczej IMŻ nr S0 1009, 2020. [unpublished]. 